\title{
2020-2021年度美捷登青年科学家 研究基金评审公告
}

\author{
陈雪姣
}

武汉美捷登生物科技有限公司

武汉美捷登生物科技有限公司 (以下简称美捷 登) 在创始人夏华向教授的带领下, 一直秉承创建 初衷不遗余力致力于国内科研论文发表事业, 经过 十余年的精心打造, 已经成长为国内英文科技论文 编辑行业的领先品牌。同时, 我们也从源头上注重 培养生物医学领域青年科学家们的科研及论文写作 能力。

为践行美捷登的社会责任, 同时切实帮助到有 困难的青年科学家或研究生, 美捷登于 2010 年设立 了「美捷登青年科学家学术及研究基金」(Medjaden Academy \& Research Foundation for Young Scientists, MARFYS), MARFYS 由三个部分组成, 分别 是美捷登青年科学家论文写作与发表基金 (简称 “论 文基金”) 、美捷登青年科学家学术会议基金 (简称 “会议基金”) 和美捷登青年科学家研究基金 (简称 “研究基金”)。只要您有需求, 并符合相应基金的 申请条件, 我们都欢迎您积极提出申请, 美捷登将 竭力为您提供帮助。

作为中国首家提供基金资助项目的论文编辑公 司, 美捷登一直在思考和改进, 我们衷心希望通过 该计划的实施真正帮助到有需要的人, 同时为申请 者提供简单便捷的渠道, 不给申请者带来任何不必 要的负担和麻烦。美捷登论文基金于 2010 年设立, 并逐步进行了升级完善。现在, 针对文章有发表潜 力但经济困难的 (英文) 论文作者, 美捷登将提供最 高全额服务费 (校对、标准编辑或深度编辑) 的资 助。 2011 年, 美捷登又先后设立了 “会议基金” 和
“研究基金”，也深受广大青年科学家的赞许和青睐。 其中，“会议基金” 旨在支持研究人员走出实验室、 走出国门去参加国内、国际会议进行学习和交流 ; “研 究基金” 则作为 “种子” 基金, 旨在为刚起步的青 年科学家们提供课题经费支持, 为后续申请更大的 项目打下基础。此外，“研究基金” 的评审工作由 多位美捷登相关领域的专家完成, 现已被越来越多 的申请者当成了撰写课题设计的 “试金石” 和 “操练 场”，获得了广泛的关注。

截至目前, 美捷登通过 MARFYS 项目已累计对 外提供基金资助，共计人民币近 130 万元。我们诚 挚欢迎广大的青年科学家们积极关注, 并踊跃申请 MARFYS (会议基金、研究基金、论文写作与发表 基金)，先到先得，机不可失!

研究基金与论文发表基金 (英文简称 MASYS)、 会议基金 (英文简称 MCSYS) 不同，只在每年 11 月 份接受申请, 次年 2 月至 3 月公布终审及资助结果。 截至 2020 年 11 月底, 美捷登学术部一共收到了 26 份青年科学家研究基金正式申请书。经过初审簰选, 其中 18 份课题设计顺利进入专家评审阶段, 最终资 助结果将在明年 2 月份公布, 敬请期待。

此外, 美捷登青年科学家学术会议基金 (MCSYS）和美捷登青年科学家论文发表基金（MASYS） 一直开放申请中, 欢迎有需求的您们踊跃申请, 详见 美捷登官网 - 诚信与公益 - 美捷登公益版块。欲了解 更多详情, 欢迎发送邮件至: medjadenacademic@ gmail.com或致电 13628624646 垂询。 